\title{
How times have changed - HIV and AIDS in South Africa in 2011
}

At the International AIDS Conference in 2006, the UN envoy on AIDS, Stephen Lewis, described the South African government as 'Obtuse, dilatory and negligent about rolling out treatment', and its AIDS policy as 'more worthy of a lunatic fringe than of a concerned and compassionate state ... [and] wrong, immoral [and] indefensible ... The government has a lot to atone for. I'm of the opinion that they can never achieve redemption.' ${ }^{1}$ During this period, the media accused the government, under former President Mbeki, of being denialist and nicknamed the late Minister of Health, Manto Tshabalala-Msimang, 'Dr No' and 'Dr Beetroot' because of her antipathy towards antiretroviral therapy and for advocating the virtues of nutrition. ${ }^{2,3}$

Despite Lewis' pessimism, South Africa is now well on its way to redemption! In October 2009, President Zuma gave a speech described by the Treatment Action Campaign (TAC) as an historic comment on AIDS, which banished AIDS denialism and ushered in a new health era in South Africa. ${ }^{4} \mathrm{He}$ acknowledged that South Africa had a large HIV and AIDS problem, and after citing the impact of HIV and AIDS on individuals, families and South African society said: 'Let me emphasise that although we have a comprehensive strategy to tackle HIV and AIDS that has been acknowledged internationally, and though we have the largest antiretroviral programme in the world, we are not yet winning this battle. ${ }^{5}$ What policy changes did government endorse, and what are their effects?

On World AIDS Day 1 December 2009, President Zuma announced significant changes to the national AIDS prevention and treatment policies. Pregnant women would be eligible for antiretroviral therapy (ART) at 14 weeks rather than 24 weeks, all HIV-positive children under 1 year of age would be eligible for ART irrespective of CD4 count, and TB/HIV co-infected patients and multidrug-resistant TB patients with a CD4 count of $\leq 350$ cells/ $\mu$ l would be eligible for ARVs. To increase access further, President Zuma launched a national HIV counselling and testing (HCT) campaign to test 15 million people and screen them for TB by June 2011. This news made headlines the world over, signalling a new beginning and a break with the past. ${ }^{6,7}$

On 12 August 2011, the Minister of Health announced the results of the HCT campaign, and the Deputy President announced that all HIV-positive patients with a CD4 count $\leq 350$ are eligible for ARVs, so that South Africa now fully complies with WHO ART guidelines. ${ }^{8}$ Truly an achievement!

The HCT scale-up policy required changes in the way health services were provided. In 2009, the Department of Health (DoH) planned to prepare an additional 500 public ART facilities per quarter and to initiate 500000 new patients on ART between April 2010 and June 2011. To decrease waiting times at facilities, the DoH introduced provider-initiated counselling and testing (PICT) and nurse-initiated and managed ARV treatment (NIMART). In contrast to voluntary counselling and testing (VCT), PICT requires that every person accessing care at a public facility be offered an HIV test by their healthcare provider (and be screened for TB), regardless of the health service sought, while NIMART allows nurses to initiate adults and children onto ART. In April 2010, 3\% of patients in facilities were offered HIV tests and 390 nurses were trained in NIMART. To improve on this baseline, targets were set for provinces, districts and facilities to improve their HCT and NIMART performances. By June 2011, the DoH increased the percentage of clients being offered HIV tests in facilities to $8 \%$ and has trained 7492 professional nurses in diagnosing and prescribing for HIV and AIDS.
During the campaign, the private sector performed over 315000 HIV tests; the public health sector performed 13.3 million HIV tests and 8 million TB screenings and initiated 429530 patients onto treatment. With 2 million HIV-positive tests reported during the campaign and more than 1.4 million cumulatively initiated on treatment since 2004 - up from less than 100000 in 2005 - it became clear that an equally strong effort was needed to ensure good-quality ART data and to support good clinical management.

An October 2010 review found over 40 patient management systems and various non-standard non-networked monitoring systems in the public sector for monitoring ART data. To address this challenge, in May 2010 the National Health Council (NHC, comprising Ministers and health MECs) adopted a standardised register and clinical stationery to assist with capturing and tracking patient information at health facilities. The paper register adopted by the $\mathrm{NDoH}$ was a modified version of a register used in the Western Cape that had been implemented since the start of the ART programme. This paper register formed the first tier of a three-tier monitoring system approved by the NHC in December 2010.

A non-networked electronic register and a networked electronic medical record comprise tiers 2 and 3. The tiered approach provides the tools to standardise ART monitoring with a system that best suits the varied needs of facilities with a goal to facilitate standardised reporting. The system and supports information management as well as patient management throughout the provinces and nationally. The $\mathrm{NDoH}$ plans to have the electronic register working in at least one facility per district by March 2012.

South Africa has moved from pariah status to a country acclaimed for its progressive HIV policies. This is clearly the result of the right leadership at the right time! The implementation of these policies is already beginning to show dividends, as illustrated by the recently released Statistics South Africa estimates of decreasing infant and under-5 mortality rates as well as increased life expectancy rates which they attribute largely to increased access to ARVs.

This editorial has tried to illustrate the gains that have been made in combating HIV. Clearly this summary does not do justice to a highly complex set of interventions and continuing challenges or to the role played by researchers, academics, public sector managers, front-line health workers and our development partners. However, to eliminate the scourge of HIV and AIDS and its terrible twin TB, much more needs to be done - strengthening the health system based on the primary health care approach is but one strategy that is required to achieve all of the Millennium Development Goals.

\section{Y Pillay}

National Department of Health

Pretoria

\section{White}

\section{N McCormick}

Clinton Health Access Initiative Pretoria

Corresponding author: Y Pillay (ypillay@intekom.co.za) Note: all authors write in their personal capacities. 


\section{References}

1. British Broadcasting Company. South African AIDS policy attacked. 19 August 2006. http://news.bbc. co.uk/2/hi/5265432.stm (accessed 1 September 2011).

2. Journ-AIDS. Manto Tshababala-Msimang. http://www.journaids.org/index.php/essential information/hivaids_key_people/manto_tshabalala-msimang/ (accessed 29 August 2011).

3. Webber B. Manto Tshabalala-Msimang: South African who oversaw discredited AIDS policy, dies at 69. New York Times website, 2009. http://www.nytimes.com/2009/12/17/world/africa/17manto.html (accessed 29 August 2009).

4. South African Press Association. TAC praises Zuma for Aids speech. 2009. http://www.iol.co.za/news/ politics/tac-praises-zuma-for-aids-speech-1.463197 (accessed 1 September 2011).
5. Zuma J. Address by the President of the Republic of South Africa, HE Mr Jacob Zuma, to the National Council of Provinces (NCOP), NCOP Chamber, Cape Town, 2009. South African Government
website, 2009. http://www.info.gov.za/speech/DynamicAction?pageid=461\&sid=5322\&tid=5467 (accessed 1 September 2009).

6. The Lancet. HIV/AIDS: A new South Africa takes responsibility. 2009. http://download.thelancet.com/ 6. The Lancet. HIV/AIDS: A new South Africa takes responsibility. 2009. http://do
flatcontentassets/pdfs/S0140673609620651.pdf (accessed 25 September 2009).

7. Dugger CW. Breaking with past, South Africa issues broad AIDS policy. New York Times website, 2009. http://www.nytimes.com/2009/12/02/world/africa/02safrica.html (accessed 25 August 2011). 8. South African Press Association. ARV program open to all now. 2011. http://www.sundaytribune. co.za/arv-program-open-to-all-now-1.1116850 (accessed 1 September 2011). 